\title{
NESTROFT-A Cost-Effective Mass Screening Tool for the Detection of $\beta$-Thalassemia Carrier Status in Anemic Pregnant Women: A Step Toward Reducing the National Disease Burden
}

\author{
Manasi Gosavi ${ }^{1, \odot} \quad$ Ramesh Chavan $^{1} \quad$ M. B. Bellad ${ }^{2}$ \\ ${ }^{1}$ Department of Pathology, KAHER's Jawaharlal Nehru Medical \\ College, Belagavi, Karnataka, India \\ 2Department of Obstetrics and Gynaecology, KAHER's Jawaharlal \\ Nehru Medical College, Belagavi, Karnataka, India
}

\begin{abstract}
Address for correspondence Manasi Gosavi, MD, Department of Pathology, JNMC, Nehrunagar, Belagavi, Karnataka - 590010, India (e-mail: mansi.gosavi@gmail.com).
\end{abstract}

J Lab Physicians 2021;13:368-373.

\begin{abstract}
Introduction $\beta$-Thalassemias are inherited hemoglobinopathies commonly encountered in practice. With chances of a promising cure being rare, the prevention of births with this disorder should assume priority, especially in low-resource countries. This can be achieved by the implementation of a mass screening program that is reliable and, at the same time, cost-effective.

Objectives This study focuses on the utility of Naked Eye Single Tube Red Cell Osmotic Fragility Test (NESTROFT) as a mass screening tool to detect thalassemia carriers. Hematological parameters that may predict carrier status were also evaluated.

Materials and Methods Hemoglobin estimation was performed on all consented pregnant women. If the patient was found to have hemoglobin $<11 \mathrm{~g} / \mathrm{dL}$, the blood sample was subjected to other routine hematological tests along with peripheral smear examination. NESTROFT was performed using $0.36 \%$ saline solution. Confirmation was done using high-performance liquid chromatography (HPLC).

Statistical Analysis Data obtained were tabulated using version 21 of the Statistical Package for Social Sciences. Means, standard deviations, and percentages were used to describe the sample. Chi-square test and Students' $t$ test were used to identify differences between the groups.

Results Of 441 pregnant women enrolled, 206 were found to be anemic. Nineteen (9.2\%) of the anemic pregnant women were detected to be carriers of hemoglobinopathies. Among the hematological parameters, mean red blood cell count and reticulocyte count were higher, while mean corpuscular hemoglobin concentration was lower in carriers. Also, carriers were more likely to present with microcytic hypochromic anemia. NESTROFT showed a sensitivity of $84.21 \%$, specificity of $96.25 \%$, a positive predictive value of $69.56 \%$, and a negative predictive value of $98.36 \%$. A false-positive result was

Keywords

- NESTROFT

- carrier screening

- thalassemia trait seen in $3.74 \%$ of the tests, while a false negative result was seen in $15.78 \%$ of the tests. Conclusions NESTROFT $(0.36 \%)$ can be used as a simple and cost-effective mass screening tool for the detection of carrier status. This should be followed by confirmation using HPLC or hemoglobin electrophoresis.
\end{abstract}

published online

July 9,2021
DOI https://doi.org/

$10.1055 / \mathrm{s}-0041-1732493$

ISSN 0974-2727 (c) 2021. The Indian Association of Laboratory Physicians.

This is an open access article published by Thieme under the terms of the Creative Commons Attribution-NonDerivative-NonCommercial-License, permitting copying and reproduction so long as the original work is given appropriate credit. Contents may not be used for commercial purposes, or adapted, remixed, transformed or built upon. (https://creativecommons.org/licenses/by-nc-nd/4.0/).

Thieme Medical and Scientific Publishers Pvt. Ltd. A-12, 2nd Floor, Sector 2, Noida-201301 UP, India 


\section{Introduction}

Hemoglobinopathies are genetically determined mendelian abnormalities that result in a quantitative or qualitative defect in the synthesis of globin molecules. Among the various hemoglobinopathies, $\beta$-thalassemias are seen most frequently in the Indian subcontinent (80\%). ${ }^{1}$ The global prevalence of $\beta$-thalassemia is estimated to be around $3 \%$, while in India, the prevalence varies from 3 to $17 \%$ in North India and $1.3 \%$ in South India., ${ }^{2,3}$ Based on genetic and clinical features, thalassemias have been classified as thalassemia major, thalassemia intermedia, thalassemia trait, and thalassemia minima. ${ }^{4}$

Thalassemia major patients present with classical clinical features of pallor, irritability, growth retardation, hepatosplenomegaly, jaundice, and skeletal deformities. These patients are dependent on blood transfusions every 3 weeks along with chelation therapy, failing which their lifespan will be sadly shortened. ${ }^{5}$ The economic implications for the affected individuals are tremendous. The cost of treatment of one thalassemic child of around 3 years of age is around INR 90,000 to $1,00,000$ annually and with progressing age, the costs would only increase proportionally. ${ }^{6}$ Bone marrow transplantation is a potentially promising cure, but involves high cost in addition to compatible donor availability and successful transplant. Thus, it is imperative that prevention must be sought rather than a cure. ${ }^{7}$ Screening for $\beta$-thalassemia trait is a major step in this direction, as such individuals are generally asymptomatic themselves but serve as carriers.

In this study, we evaluated the utility of Naked Eye Single Tube Osmotic Fragility Test (NESTROFT) as a simple and inexpensive screening method for the detection of $\beta$-thalassemia trait in anemic pregnant women. This group was chosen for the study since pregnant women present regularly to the hospital for checkups, blood investigations are routinely done, and the would-be parents are more receptive toward tests being done for the well-being of their unborn child. ${ }^{8}$

\section{Aims and Objectives}

Following are the aims and objectives of this article:

1. To estimate the utility of NESTROFT as a simple and inexpensive screening method to detect $\beta$-thalassemia trait in anemic pregnant women.

2. To compare the hematological parameters of anemic pregnant women who are carriers as compared with noncarriers.

\section{Materials and Methods}

This cross-sectional study was conducted over a period of 1 year in a tertiary care facility after obtaining institutional ethics committee approval. All consented pregnant women who presented to the obstetrics outpatient department were interviewed using a specially prepared proforma that included demographic data along with information pertaining to the present pregnancy, significant past medical history, and family history. Three milliliters of venous blood were collected in an ethylene-diamine-tetraacetic-acid vacutainer under strict aseptic precautions. Hemoglobin estimation was performed and if the woman was found to have hemoglobin $<11 \mathrm{~g} / \mathrm{dL}$, then the blood sample was subjected to other routine hematological tests like complete blood count, packed cell volume, mean corpuscular volume (MCV), mean corpuscular hemoglobin $(\mathrm{MCH})$, mean corpuscular hemoglobin concentration (MCHC), red cell distribution width (RDW), and peripheral smear examination.

NESTROFT was performed using $0.36 \%$ saline solution as first suggested by Kattamis et al, who showed that this concentration was sensitive and effectively detected 96\% of $\beta$-thalassemia carriers. ${ }^{9}$ The stock solution was prepared using sodium chloride (90 g), disodium hydrogen phosphate (13.65 g), sodium dihydrogen phosphate (2.43 g), and distilled water $(1,000 \mathrm{~mL})$. Two milliliters of $0.36 \%$ buffered saline were taken in a test tube labeled as "Test," while $2 \mathrm{~mL}$ of distilled water was taken in the "Control" tube. One drop of the subjects' blood was added to each tube and placed on a stand after mixing well. After 30 minutes, both the tubes were held against a black line on a white background. If the black line was blurred, it was considered positive; if clearly visible, it was interpreted as negative. This test is based on the reduced osmotic fragility demonstrated by microcytic red cells as compared with normal red cells. ${ }^{6}$ Confirmation of carrier status was done using high-performance liquid chromatography.

Data obtained were tabulated using version 21 of the Statistical Package for Social Sciences. Means, standard deviation (SD), and percentages were used to describe the sample.

Chi-square test and Students' $t$ test were used in identifying differences between the groups.

\section{Observations and Results}

A total of 441 pregnant women were screened for anemia, of which 206 were anemic (46.7\%). - Table 1 shows the sociodemographic data of anemic pregnant women. About $53.41 \%$ were between the ages of 21 and 25 years; $70.88 \%$ came from a rural setting. Out of these 206 pregnant women, 19 women (9.2\%) were detected to be carriers of hemoglobinopathies, which included 16 cases of $\beta$-thalassemia trait, and 1 case each of delta- $\beta$ thalassemia trait, sickle cell trait, and hereditary persistence of fetal hemoglobin. Of the 19 women who were carriers of hemoglobinopathies, 1 was in the first trimester while 9 each were in the second and third trimester. Fifty-six women of the anemic group and six of the carrier group (total of $30.08 \%$ ) were consanguineously married. The obstetric history pertaining to the rates of abortion between carriers (mean: $0.11 \pm 0.072 \mathrm{SD}$ ) and anemic group (mean: $-0.8 \pm 0.024 \mathrm{SD}$ ) were statistically insignificant. About $4.85 \%$ of the anemic women without hemoglobinopathies had received prior blood transfusions, while $0.48 \%$ of the carriers had received transfusions earlier.

Various hematological parameters were compared between anemic noncarriers and women who were carriers of hemoglobinopathies ( - Table 2). It was observed that the 
Table 1 Sociodemographic data comparison between anemic pregnant women with and without hemoglobinopathies ( $n=206)$

\begin{tabular}{|c|c|c|c|c|c|c|c|}
\hline \multirow{2}{*}{\multicolumn{2}{|c|}{ Variable }} & \multicolumn{2}{|c|}{$\begin{array}{c}\text { Anemia without } \\
\text { hemoglobinopathy }\end{array}$} & \multicolumn{2}{|c|}{$\begin{array}{c}\text { Anemia with } \\
\text { hemoglobinopathy }\end{array}$} & \multirow[t]{2}{*}{$\begin{array}{l}t \text {-Value I } \\
\mathrm{X}^{2} \text { value }\end{array}$} & \multirow[t]{2}{*}{$p$-Value } \\
\hline & & $n /$ mean & $\% / S D$ & $n /$ mean & $\% / S D$ & & \\
\hline \multirow[t]{4}{*}{ Age groups } & $15-20$ & 57 & 93.44 & 4 & 6.56 & 1.305 & 0.728 \\
\hline & $21-25$ & 98 & 89.10 & 12 & 10.90 & & \\
\hline & $26-30$ & 28 & 90.32 & 3 & 9.68 & & \\
\hline & $31-35$ & 4 & 100 & 0 & 0 & & \\
\hline \multicolumn{2}{|l|}{ Age } & 22.7 & 3.30 & 23.21 & 2.485 & 0.654 & 0.514 \\
\hline \multirow[t]{2}{*}{ Residence } & Rural & 130 & 89.04 & 16 & 10.96 & \multirow[t]{2}{*}{1.803} & \multirow[t]{2}{*}{0.179} \\
\hline & Urban & 57 & 95.0 & 3 & 5.0 & & \\
\hline \multirow[t]{3}{*}{ Religion } & Hindu & 165 & 90.66 & 17 & 9.34 & \multirow[t]{3}{*}{0.112} & \multirow[t]{3}{*}{0.945} \\
\hline & Muslim & 21 & 91.30 & 2 & 8.70 & & \\
\hline & Christian & 1 & 100 & 0 & 0 & & \\
\hline \multirow{2}{*}{$\begin{array}{l}\text { Marital } \\
\text { Status }\end{array}$} & Married & 186 & 90.73 & 19 & 9.27 & \multirow[t]{2}{*}{0.102} & \multirow[t]{2}{*}{0.749} \\
\hline & Unmarried & 1 & 100 & 0 & 0 & & \\
\hline \multirow[t]{4}{*}{ Occupation } & Homemaker & 170 & 90.91 & 17 & 9.09 & \multirow[t]{4}{*}{1.841} & \multirow[t]{4}{*}{0.606} \\
\hline & Laborer & 6 & 100 & 0 & 0 & & \\
\hline & Office work & 3 & 75 & 1 & 25 & & \\
\hline & Others & 8 & 88.89 & 1 & 11.11 & & \\
\hline \multirow[t]{5}{*}{ Education } & Illiterate & 9 & 100 & 0 & 0 & \multirow[t]{5}{*}{2.723} & \multirow[t]{5}{*}{0.605} \\
\hline & Read and write & 5 & 83.33 & 1 & 16.67 & & \\
\hline & Primary & 29 & 85.30 & 5 & 14.70 & & \\
\hline & High school & 131 & 91.60 & 12 & 8.40 & & \\
\hline & Graduate & 13 & 92.85 & 1 & 7.15 & & \\
\hline
\end{tabular}

Abbreviation: SD, standard deviation.

mean red blood cell $(\mathrm{RBC})$ count in carriers (4.03 million) was higher, the mean MCHC (33.42\%) was lower, and the mean reticulocyte count $(2.10 \%)$ was higher as compared with anemics who were noncarriers (3.75 million, $34.28 \%$ and $0.99 \%$, respectively). These differences were statistically significant. Other differences that were not statistically significant but were nevertheless present were that the $\mathrm{RDW}, \mathrm{MCV}$, and $\mathrm{MCH}$ were lower in the carriers as compared with the noncarriers. Among the patterns of anemia seen, it was observed that carriers were more likely to present with microcytic hypochromic anemia and this finding was statistically significant.

NESTROFT was positive in 16 out of 19 subjects with hemoglobinopathies. It could accurately identify $87.38 \%$ of the women who did not have hemoglobinopathies and this finding was statistically significant. The sensitivity of NESTROFT was $84.21 \%$ and it had a high specificity of $96.25 \%$. The predictive value of a negative test was very high being $98.36 \%$, which meant that it could precisely identify people who were not carriers. The predictive value of a positive test was $69.56 \%$. A false-negative test was seen in $15.78 \%$ of cases, while only $3.74 \%$ of cases showed a false-positive test ( - Table 3 ).

\section{Discussion}

Hemoglobinopathies, especially thalassemias, constitute the most common fatal hereditary disorders and they are responsible for a significant amount of morbidity and mortality. Ignorance about the disorder and lack of knowledge regarding the genetics of thalassemia contributes significantly toward increasing the disease burden. Community education through awareness programs along with large-scale carrier screening are the pillars upon which the control of disease burden rests. Population screening in various settings is practiced to a certain extent, for example, extended family screening or community studies performed in certain high-risk groups. Premarital screening and screening of school-going children pose logistic, social, and economic constraints. ${ }^{5}$ Antenatal screening for hemoglobinopathies, if made part of routine antenatal tests, could prove to be successful. If the pregnant lady is found to be a carrier, the partner can be tested for carrier status following the results of which prenatal diagnosis and appropriate genetic counseling can be offered.

The prevalence of hemoglobinopathies varies between 3 and $17 \%$ in different states and populations in India. ${ }^{10}$ In the 
Table 2 Hematological investigations in anemic pregnant women with and without hemoglobinopathies

\begin{tabular}{|c|c|c|c|c|c|c|c|c|}
\hline \multirow[t]{2}{*}{ SI. no. } & \multirow{2}{*}{\multicolumn{2}{|c|}{ Variable }} & \multicolumn{2}{|c|}{$\begin{array}{c}\text { Anemia without } \\
\text { hemoglobinopathy }\end{array}$} & \multicolumn{2}{|c|}{$\begin{array}{c}\text { Anemia with } \\
\text { hemoglobinopathy }\end{array}$} & \multirow[t]{2}{*}{$\begin{array}{l}t \text {-Value } / x^{2} \\
\text { value }\end{array}$} & \multirow[t]{2}{*}{$p$-Value } \\
\hline & & & $n /$ mean & $\% / S D$ & $n /$ mean & $\% / S D$ & & \\
\hline 1 & \multicolumn{2}{|l|}{ Hemoglobin } & 9.36 & 1.23 & 9.50 & 1.09 & -0.456 & 0.649 \\
\hline 2 & \multicolumn{2}{|l|}{ RBC count } & 3.75 & 0.58 & 4.03 & 0.69 & -1.998 & $0.047^{a}$ \\
\hline 3 & \multicolumn{2}{|l|}{ Hematocrit } & 27.37 & 3.34 & 28.23 & 3.32 & -1.100 & 0.273 \\
\hline 4 & \multicolumn{2}{|l|}{ RDW } & 16.86 & 2.95 & 16.15 & 2.64 & 1.014 & 0.312 \\
\hline 5 & \multicolumn{2}{|l|}{ MCV } & 74.11 & 8.58 & 71.47 & 10.78 & 1.246 & 0.214 \\
\hline 6 & \multicolumn{2}{|l|}{$\mathrm{MCH}$} & 25.46 & 3.77 & 24.02 & 4.67 & 1.555 & 0.121 \\
\hline 7 & \multicolumn{2}{|l|}{$\mathrm{MCHC}$} & 34.28 & 1.47 & 33.42 & 1.94 & 2.368 & $0.019^{a}$ \\
\hline 8 & \multicolumn{2}{|l|}{ ESR } & 21.90 & 10.24 & 21.47 & 10.04 & 0.175 & 0.861 \\
\hline 9 & \multicolumn{2}{|l|}{ Retic count } & 0.99 & 0.29 & 2.10 & 0.46 & 14.965 & $0.000^{\mathrm{a}}$ \\
\hline 10 & \multicolumn{2}{|l|}{ Total count } & $10,585.56$ & $4,184.37$ & $9,421.05$ & $2,876.07$ & 1.184 & 0.238 \\
\hline 11 & \multicolumn{2}{|l|}{ Neutrophils } & 75.98 & 6.49 & 73.84 & 7.29 & 1.352 & 0.178 \\
\hline 12 & \multicolumn{2}{|c|}{ Lymphocytes } & 20.55 & 5.81 & 22.37 & 6.28 & 1.293 & 0.197 \\
\hline 13 & \multicolumn{2}{|l|}{ Eosinophils } & 1.59 & 1.22 & 1.79 & 1.65 & 0.661 & 0.510 \\
\hline 14 & \multicolumn{2}{|l|}{ Monocytes } & 1.91 & 1.42 & 2.00 & 1.49 & 0.249 & 0.804 \\
\hline 15 & \multicolumn{2}{|c|}{ Abs granulocyte } & 8.24 & 3.70 & 7.12 & 2.31 & 1.290 & 0.198 \\
\hline 16 & \multicolumn{2}{|c|}{ Abs lymphocyte } & 2.04 & 0.70 & 1.94 & 0.64 & 0.612 & 0.541 \\
\hline 17 & \multicolumn{2}{|c|}{ Abs monocyte } & 0.35 & 0.22 & 0.36 & 0.24 & 0.206 & 0.837 \\
\hline 18 & \multicolumn{2}{|c|}{ Platelet count } & $290,395.72$ & $89,862.64$ & $287,684.21$ & $87,084.28$ & 0.126 & 0.900 \\
\hline 19 & \multicolumn{2}{|l|}{ MPV } & 8.03 & 0.91 & 8.11 & 1.03 & 0.361 & 0.719 \\
\hline 20 & \multicolumn{2}{|l|}{$\mathrm{PCT}$} & 0.40 & 2.29 & 0.23 & 0.07 & 0.325 & 0.746 \\
\hline 21 & \multicolumn{2}{|l|}{ PDW } & 12.68 & 2.51 & 12.92 & 2.68 & 0.380 & 0.704 \\
\hline \multirow[t]{3}{*}{22} & \multirow{3}{*}{$\begin{array}{l}\text { Patterns of } \\
\text { anemia }\end{array}$} & $\mathrm{MHA}$ & 54 & 26.21 & 12 & 5.83 & 9.227 & $0.010^{\mathrm{a}}$ \\
\hline & & $\mathrm{NHA}$ & 106 & 51.46 & 7 & 3.39 & 2.742 & 0.98 \\
\hline & & $\mathrm{DA}$ & 27 & 13.11 & 0 & 0 & 3.157 & 0.076 \\
\hline
\end{tabular}

Abbreviations: DA, dimorphic anemia; ESR, erythrocyte sedimentation rate; MCHC, mean corpuscular hemoglobin concentration; MCV, mean corpuscular volume; MHA, microcytic hypochromic anemia; MPV, mean platelet volume; NHA, normocytic hypochromic anemia; PCT, platelet count; PDW, platelet distribution width; RBC, red blood cell; RDW, red cell distribution width; SD, standard deviation.

aStatistically significant $(p<0.05)$.

Table 3 NESTROFT as a screening test for the detection of hemoglobinopathies $(n=206)$

\begin{tabular}{|c|c|c|c|c|c|c|c|}
\hline \multirow{2}{*}{\multicolumn{2}{|c|}{ Variable }} & \multicolumn{2}{|c|}{$\begin{array}{c}\text { Anemia without } \\
\text { hemoglobinopathy }\end{array}$} & \multicolumn{2}{|c|}{$\begin{array}{c}\text { Anemia with } \\
\text { hemoglobinopathy }\end{array}$} & \multirow[t]{2}{*}{$\begin{array}{l}t \text {-Value/ } X^{2} \\
\text { value }\end{array}$} & \multirow[t]{2}{*}{$p$-Value } \\
\hline & & \multirow{2}{*}{$\begin{array}{l}n / \text { mean } \\
7\end{array}$} & \multirow{2}{*}{$\begin{array}{l}\% / S D \\
30.44\end{array}$} & \multirow{2}{*}{\begin{tabular}{|l|}
$n /$ mean \\
16
\end{tabular}} & \multirow{2}{*}{$\begin{array}{l}\% / S D \\
69.56\end{array}$} & & \\
\hline NESTROFT & Positive & & & & & 112.596 & $0.000^{\mathrm{a}}$ \\
\hline & Negative & 180 & 98.36 & 3 & 1.64 & & \\
\hline \multicolumn{4}{|l|}{ Sensitivity } & \multicolumn{4}{|c|}{$84.21 \%$} \\
\hline \multicolumn{4}{|l|}{ Specificity } & \multicolumn{4}{|c|}{$96.25 \%$} \\
\hline \multicolumn{4}{|c|}{$\%$ False negative } & \multicolumn{4}{|c|}{$15.78 \%$} \\
\hline \multicolumn{4}{|c|}{$\%$ False positive } & \multicolumn{4}{|c|}{$3.74 \%$} \\
\hline \multicolumn{4}{|c|}{ Predictive value of positive test } & \multicolumn{4}{|c|}{$69.56 \%$} \\
\hline \multicolumn{4}{|c|}{ Predictive value of negative test } & \multicolumn{4}{|c|}{$98.36 \%$} \\
\hline
\end{tabular}

Abbreviations: NESTROFT, Naked Eye Single Tube Red Cell Osmotic Fragility Test; SD, standard deviation.

a Statistically significant $(p<0.05)$.

present study, the percentage of carriers detected was $9.2 \%$. This high prevalence could be due to the existing sociocultural practices unique to this part of the country where consanguineous marriages with maternal kindred are an accepted norm. The present study was undertaken to study the utility of NESTROFT as a screening method using a buffered saline solution of $0.36 \%$, as studies have indicated that this concentration could detect $97.7 \%$ of the heterozygous $\beta$-thalassemia 
Table 4 NESTROFT-Comparison with other studies

\begin{tabular}{|l|l|l|l|l|l|l|}
\hline & $\begin{array}{l}\text { Present } \\
\text { study }\end{array}$ & $\begin{array}{l}\text { Chakrabarti } \\
\text { et al }{ }^{10}(\mathbf{2 0 1 2})\end{array}$ & $\begin{array}{l}\text { Sumera } \\
\text { et al }^{16} \text { (2012) }\end{array}$ & $\begin{array}{l}\text { Vijay } \\
\text { et al }^{11} \text { (2010) }\end{array}$ & $\begin{array}{l}\text { Singh and Gupta } \\
\text { et al }^{\text {(2008) }}\end{array}$ & $\begin{array}{l}\text { Sirichotiyakul } \\
\text { et al }^{12}(\mathbf{2 0 0 4})\end{array}$ \\
\hline Sensitivity (\%) & 84.21 & 94.12 & 93 & 100 & 97.7 & 97.6 \\
\hline Specificity (\%) & 96.25 & 95.2 & 84 & 98.5 & 83.3 & 72.9 \\
\hline $\begin{array}{l}\text { Positive predic- } \\
\text { tive value (\%) }\end{array}$ & 69.56 & 41.02 & 78 & 96 & 95.5 & 33.6 \\
\hline $\begin{array}{l}\text { Negative predic- } \\
\text { tive value (\%) }\end{array}$ & 98.36 & 99.7 & 97 & 100 & 90.9 & 99.5 \\
\hline
\end{tabular}

Abbreviation: NESTROFT, Naked Eye Single Tube Red Cell Osmotic Fragility Test.

patients with a specificity of $83.3 \% .^{10}$ - Table 4 compares the sensitivity, specificity, positive predictive value, and negative predictive value of NESTROFT with other similar studies. The sensitivity in the present study was slightly less as compared with other studies, the probable cause being a larger sample size in the other studies. Specificity and negative predictive value in the present study is comparable to results obtained by Chakrabarti et al and Vijay et al. ${ }^{11,12}$ The positive predictive value of the test shows a wide variation ranging from 33.6 to $96 \%{ }^{12,13}$ Our study shows a positive predictive value of $69.56 \%$. High sensitivity and specificity are desirable factors for judging the effectiveness of a screening test. A high negative predictive value almost rules out the possibility of a $\beta$-thalassemia trait.

Among the hematological parameters used to distinguish $\beta$-thalassemia carriers, the decrease in hemoglobin is minimal in heterozygous thalassemia cases. ${ }^{14}$ The mean RBC count is increased as compared with normal and the mean RDW is lower in $\beta$-thalassemia carriers. These two features are useful in differentiating thalassemia traits from iron deficiency anemia, both of which present with a microcytic hypochromic picture. Iron deficiency anemia, however, presents with a reduced red cell count and increased RDW, whereas $\beta$-thalassemia carriers present with uniform microcytosis. ${ }^{4}$ Few studies have suggested that an MCV of 72 femtolitres is maximally sensitive and specific for presumptive diagnosis of thalassemia cases. ${ }^{14,15}$ Thalassemia carriers also have a higher reticulocyte count, especially in hematologically stressful conditions such as pregnancy. ${ }^{4}$

A national thalassemia screening program is the need of the hour, especially in a country like ours that lies along the thalassemia belt. Mass screening programs involving antenatal diagnosis followed by genetic counseling and public education have shown huge success rates in countries such as Greece, Cyprus, and Italy that have reduced thalassemia incidence by 52,96 , and $62 \%$, respectively. ${ }^{5}$ In a resource-poor country like ours, a viable and effective test can help us take huge steps along the road of thalassemia prevention. NESTROFT is an ideal screening test as it is simple, cheap (costs INR 1.5/test, and does not require expensive equipment). ${ }^{6}$

\section{Conclusion}

This study addressing screening of $\beta$-thalassemia carriers performed in antenatal population is rare. The results of this study establish NESTROFT as a cost-effective mass screening tool for the detection of carriers. NESTROFT has a sensitivity of $84.21 \%$, specificity of $96.25 \%$, negative predictive of $98.36 \%$, and a positive predictive value of $69.56 \%$. If the pregnant subject is detected to be a carrier, further testing of the partner is indicated followed by chorionic villous sampling and genetic counseling where indicated.

\section{Limitations of the Study}

This study is limited by the small sample size as it is a facility-based study conducted in a tertiary care hospital. A wide-scale population-based study with a larger sample size is desirable.

\section{Conflict of Interest}

None declared.

\section{References}

1 Mulchandani DV, Fulare MB, Zodpey SP, Vasudeo ND. Prevalence and some epidemiological factors of beta thalassaemia trait in Sindhi community of Nagpur City, India. Indian J Public Health 2008;52(1):11-15 [published correction appears in Indian J Public Health. 2008 Jan-Mar;52(1):following 52]

2 Piplani S, Manan R, Lalit M, Manjari M, Bhasin T, Bawa J. NESTROFT - A valuable, cost effective screening test for beta thalassemia trait in North Indian Punjabi population. J Clin Diagn Res 2013;7(12):2784-687

3 Patel P, Sarda N, Arora R, Gaikwad HS. Comparative evaluation of NESTROFT and RDW as screening tests for beta thalassemia trait in pregnancy. Int J Reprod Contracept Obstet Gynecol 2015;4(2):424-428

4 Tim RR, Thalassemia. In: McKenzie SB, Williams JL, eds. Clinical Laboratory Hematology. 2nd edition. New York: Pearson; 2009 231-256

5 Rakholia R, Chaturvedi P. Prevalence of $\beta$ thalassemia carrier state in Sindhi community of Wardha and evaluation of risk factors for $\beta$ thalassemia trait. Niger J Clin Pract 2013;16(3):375-380

6 Kulkarni P, Masthi NR, Niveditha S, Suvarna R. The prevalence of the beta thalassemia trait among the pregnant women who attended the ANC clinic in a PHC, by using the NESTROF test in Bangalore, Karnataka. J Clin Diagn Res 2013;7(7):1414-1417

7 Mamtani M, Das K, Jawahirani A, Rughwani V, Kulkarni H. Is NESTROFT sufficient for mass screening for beta-thalassaemia trait? J Med Screen 2007;14(4):169-173

8 Baxi A, Manila K, Kadhi P, Heena B. Carrier screening for $\beta$ thalassemia in pregnant Indian women: experience at a single center in Madhya Pradesh. Indian J Hematol Blood Transfus 2013;29(2):71-74 
9 Colah RB. The use of NESTROFT for screening pregnant women for detection of $\beta$-thalassemia carriers. J Foetal Med 2015;2:9-10

10 Singh SP, Gupta SC. Effectiveness of red cell osmotic fragility test with varying degrees of saline concentration in detecting beta-thalassaemia trait. Singapore Med J 2008;49(10):823-826

11 Chakrabarti I, Sinha SK, Ghosh N, Goswami BK. Beta thalassemia carrier detection by NESTROFT: an answer in rural scenario? Iran J Pathol 2012;7(1):19-26

12 Vijay B, Gupta S, Gupta R. Detection of carriers for $\beta$-thalassemia: a case study of Jammu (J\&K. Orient J Chem 2010;26(1):199-206

13 Sirichotiyakul S, Tantipalakorn C, Sanguansermsri T, Wanapirak C, Tongsong T. Erythrocyte osmotic fragility test for screening of alpha-thalassemia- 1 and beta-thalassemia trait in pregnancy. Int J Gynaecol Obstet 2004;86(3):347-350

14 Tyagi S, Dass J, Sharma M, Diagnosis of thalassemia and hemoglobinopathies. In: Agarwal MB, ed. Haematology Today. Mumbai: Agarwal Publisher; 2010 91-101

15 Lafferty JD, Crowther MA, Ali MA, Levine M. The evaluation of various mathematical RBC indices and their efficacy in discriminating between thalassemic and non-thalassemic microcytosis. Am J Clin Pathol 1996;106(2):201-205

16 Sumera A, Ahmed S, Ali MA, Khanani R. Evaluation of NESTROFT as a marker of differentiation between $\beta$-thalassemia trait \& iron deficiency anemia. Int J Collab Res Intern Med Public Health 2012;4:1560-1566 